\title{
News Media and the Öresund Region
}

\author{
A Case of Horizontal Europeanisation?
}

\author{
Jesper Falkheimer, Mark Blach-Ørsten, \\ Mads Kæmsgaard Eberholst \& Veselinka Möllerström
}

\begin{abstract}
This article presents a first attempt to investigate the news content and news routines of Danish and Swedish news media covering the Öresund region. From a theoretical perspective, the Öresund region can be considered a possible best-case example of what is categorised as horizontal Europeanisation, in other words, of the potential for increased communication linkages in news media content among European Union (EU) member states. We investigate this topic by analysing news content published by selected media outlets from 2002 to 2012 and by interviewing Danish and Swedish journalists who cover the region. We find that most news content does not mention the Öresund region, and that one reason for this lack might be that neither Danish nor Swedish reporters consider the region to be newsworthy.
\end{abstract}

Keywords: news media, horizontal Europeanisation, Öresund, Denmark, Sweden, journalism

\section{Introduction}

When the Öresund Bridge was inaugurated in 2000, it physically connected Denmark and Sweden, nations that had been separated since Denmark was invaded from southern Sweden in 1658. Historically, periods after 1658 have seen Danish-Swedish co-operation. An early example is the Scandinavism movement partly organized by university students in Lund, Sweden, and Copenhagen, Denmark, which increased transnational co-operation between the countries (and Norway) during the mid-1800s. During the 1960s, talk of a futuristic vision of a Danish-Swedish region called Örestad arose in political and corporate spheres but faded when economic recession hit during the 1970s. In the 1990s, the political and economic discourse on transnational regions in Europe grew stronger again. Today, Öresund is recognised as a cross-border region in the European Union (EU) and has 3.8 million inhabitants and strong business clusters in, for example, information and communications technology (ICT), medical technology and tourism. The Öresund region is an important part to the Swedish and Danish economies and contributes 26 per cent of the two nation's GDP. The region has 14 universities and higher education institutions, some of which are highly ranked globally ${ }^{1}$.

Falkheimer, Jesper; Blach-Ørsten, Mark; Eberholst, Mads Kæmsgaard \& Möllerström, Veselinka (2017). News Media and the Öresund Region. A Case of Horizontal Europeanisation? Nordicom Review 38(1): 1-15. doi:10.1515/nor-2016-0041 
The main argument behind investing in a bridge was, as in the 1960s, economic growth (Falkheimer 2004). The connection between Denmark and Sweden was expected to lead to increased economic prosperity due to improved logistical mobility and synergies resulting from new corporate collaborations. A second main argument was cultural identity. Several actors and institutions strongly believed that the physical connection would lead to the development of a transnational identity and common Danish-Swedish public sphere.

Around 2000, various media and communication projects concerning Öresund were underway. EU-Interreg sponsored a collaborative project between Danish and Swedish public-service television news actors. The Danish newspaper Berlingske Tidende and the Swedish Sydsvenskan briefly ran a common supplement. Since 2000, the Öresund Committee has branded the region as 'Öresund: The Human Capital', created a branding organisation (Öresund Identity Network) and launched various promotional activities. The branding organisation, however, was dismantled after some years primarily as the brand strategy achieved only weak effects. The Öresund identity had been 'artificially created by a group of politicians and [did] not reflect the feeling the majority of the inhabitants have: most feel still Danes and Swedish in the first place rather than residents from the Euro region of the Öresund (Hospers 2006:1028). Almost all forms of co-operation between the Danish and Swedish news media were also put on hold indefinitely.

Today, the mobility between Denmark and Sweden has increased greatly ${ }^{2}$, but cultural integration and the creation of a common public sphere have not advanced as far (Hall 2008, Löfgren 2008). This article thus picks up where the most recent studies have left off. We analyse 2002-2012 news coverage of the region in Danish and Swedish newspapers to see if a more common mediated public sphere emerged during the same time that mobility between Denmark and Sweden increased. We also interview journalists working for Danish and Swedish newspapers about how they cover the region and what obstacles and challenges they face in doing so.

\section{Transnational regions and the news media}

According to much theorising on the successful development of transnational regions, the news media play highly important roles in creating and making sense of place and space (Lamour \& Lorentz 2016, Jansson \& Falkheimer 2006). The development of nationalism and the modern nation-state as an imagined community have been connected to the growth of print media in Europe (Andersen 2003), while the emergence of the globalised imagined community has been connected to international television news (Hannerz 1996) and the rise of the Internet.

The media also feature prominently in the few studies on the Öresund region. Both Falkheimer (2004) and Stöber (2004) assume that the news media play important roles in the development of a well-functioning region. In Stöber's (2004) view, journalists working in the news media are part of the critical infrastructure that 'implements ideas of culture and solidifies ways of life by producing images by which we define our place in the world' (113). Other key actors in this critical infrastructure include politicians, academics and regional leaders. The news media in Denmark and Sweden contribute to the development of the Öresund region by constructing a mediatised image of the region which helps inhabitants better imagine their new shared community, in line with 
the writings of Benedict Anderson (1983). However, Falkheimer (2004) also warns that the media remain very locally and nationally focused and populated with stereotypes of different national identities and so can hinder as well as aid the development of a common regional identity.

Grieves (2012) picks up the debate over the existence of a national sphere outside the nation-state in a study on news coverage in the Sar-Lor-Lux region of Central Europe. Grieves (2012) argues that the process of Europeanisation is shaped not only by national differences but also by regional specificities. Therefore, studies of Europeanisation should treat European regions as important units of analysis as nations.

\section{Horizontal Europeanisation and transborder journalism in the Öresund region}

As is clear from these studies, the news media, along with politicians and others, may play important roles in the critical infrastructure needed to create a well-functioning region. However, the production of news and especially the different journalistic cultures in various countries might also hinder building of a region. In analysing the news media's coverage of the Öresund region, clear parallels can be drawn with the general discussion on the Europeanisation of the news media, in other words, the news media's role in coverage of the EU. Studies on Europeanisation sometimes differentiate between different kinds of Europeanisation. Koopmans and Erbe (2004), Brüggermann and Köningslöw (2009) and Kandyla and de Vreese (2011) identify: vertical Europeanisation and horizontal Europeanisation. Vertical Europeanisation can be defined as increased communicative linkages in news media content between the national level (often the national Parliament and national politicians) and the European level (Brussels and EU institutions and actors). Horizontal Europeanisation can be defined as increased communicative linkages in news media content between EU member states. Koopmans and Erbe (2004) further distinguish between weak and strong horizontal Europeanisation. In weak horizontal Europeanisation, national news media focus on 'what happens within the national political spaces of other member states', whereas, in strong horizontal Europeanisation, they create 'direct communicative linkages between two member states political spaces’ (Koopmans \& Erbe 2004, p. 104).

So far, studies on Europeanisation in the Danish and Swedish news media have mostly focused on vertical Europeanisation (Palm 1996, Ørsten 2004, Tjernström 2008). Fewer studies have considered horizontal Europeanisation, and those have found only examples of weak horizontal Europeanisation in news media content. Most studies on horizontal Europeanisation have analysed only media content, not the journalistic practices producing the content. Grieves (2012), though, links the question of the horizontal Europeanisation of media content to a specific journalism practice he terms transborder journalism. Transborder journalism emphasises the horizontal regional connections across borders and is manifested on the ground first and foremost in the daily practices of journalists performing it (Grieves 2012.) Grieves (2012) notes that, although journalists might share many news values, news routines and cultures can vary significantly even between nations in close proximity.

Both Denmark and Sweden are placed in the democratic corporatist media system in the media systems analysis by Hallin and Mancini (2004). As Nordic welfare states, 
the countries share similar political systems, and their media systems are characterised by the early development of printed press, high degree of journalistic professionalism and clear focus on public-service news media (radio and television). Even though the countries' media and political systems are similar in many ways and more or less fulfil Hallin and Mancini's (2004) definition of the democratic corporatist media system, room for differences within the Nordic countries remains, as Falkheimer (2004) notes. One difference between the Danish and Swedish media system arises in journalistic culture. Grieves (2012) quotes Hanitzsch's definition of journalistic culture: 'Journalism culture becomes manifest in the way journalists act and think; it can be defined as a particular set of ideas and practices by which journalists, consciously and unconsciously legitimate their role in society and render their work meaningful to themselves and others'. According to Greives (2012), the practices of transborder journalism are not fixed but are constantly evolving on the ground, shaped not by a plan or policy but by how a specific journalistic culture is interpreted by individual journalists and their media organisations on a daily basis.

\section{The study: research questions and research design}

Euroregions like Öresund can, according to the research mentioned, be considered a possible best-case example of horizontal Europeanisation. This leads to the first research question on horizontal Europeanisation:

RQ 1: From 2002 to 2012, did coverage of actors or events in the other country increase in Danish and Swedish newspapers?

Although much of the critical infrastructure needed to support the successful development of a region is in place in the Öresund region, studies remind us that different journalistic cultures present a huge challenge to any kind of Europeanisation. This leads to the second research question concerning journalistic culture:

RQ 2: How do Danish and Swedish journalists think and act in regards to covering the Öresund region?

\section{Research design}

Content analysis was applied to 1396 articles from 2002 to 2012 from nine Danish and Swedish newspapers initially identified as the media covering the Öresund region. We sampled one week in November each year: the $46^{\text {th }}$ week of the year. Methodologically, this research design was inspired by Lund (2001) and Lund, Willig and Blach-Ørsten (2009), who analysed Danish news content in the $46^{\text {th }}$ week of the year in 1999,2008 and 2012 .

The analysed media are somewhat comparable. Metro Skåne (Sweden) is equivalent to MetroXpress (Denmark); both are free newspapers widely distributed to morning traffic and on public transport. Helsingørs Dagblad (Denmark) and Frederiksborg Amtsavis (Denmark) are local newspapers with a very local focus on subjects. Two Danish newspapers Politiken and Berlingske are national newspapers based in the Danish capital, whereas Sydsvenskan and Kvällsposten are Swedish regional newspapers covering southern Sweden. The articles analysed are only from the print versions, not 
the online outlets of these newspapers (even if the articles in most, if not all, cases are also published online). Focusing on print media, of course, precludes saying anything about television coverage of the Öresund region, but as Lund, Willig and Blach-Ørsten (2009) have pointed out, many stories on television stem from the newspapers.

The articles were found using various search words covering important geographical locations, cities and topics in the Öresund region in Swedish and Danish databases. Coders worked in both countries and used a common key to code the content. An intercoder-reliability test was performed on the segregated data and returned satisfying results $^{3}$. The data were then compiled into one dataset which provided the basis for this analysis. The compiled data are publicly available at http://journalismdata.ruc.dk/blog/ media-research-oresund/.

To investigate journalistic culture and practices, we conducted 17 interviews with journalists and editors from the selected newspapers. The Swedish interviews were held in September 2013 and January 2014, and the Danish interviews in February 2014. Nine Danish journalists and eight Swedish journalists were interviewed. The interviewees were selected from among the authors of many of the coded articles, so they were accustomed to reporting on Öresund. In all but one case, the Swedish interviews were conducted face to face; the exception was done by phone. Four Danish interviews were conducted face to face, and five by the phone. The Swedish sample included six men, and the Danish sample five men.

\section{Horizontal Europeanisation in Danish and Swedish media content}

\section{Newspapers and articles analysed}

The content coded is roughly distributed evenly between the two countries, with 695 articles from Swedish newspapers and 681 from Danish newspapers. However, there is one less newspaper included in the Swedish results. Thus, the fewer Swedish newspapers produced more articles than the Danish newspaper, indicating less interest in and coverage of the Öresund region in Danish newspapers. This implication is also supported by the interviews with editors and journalists discussed in the next section.

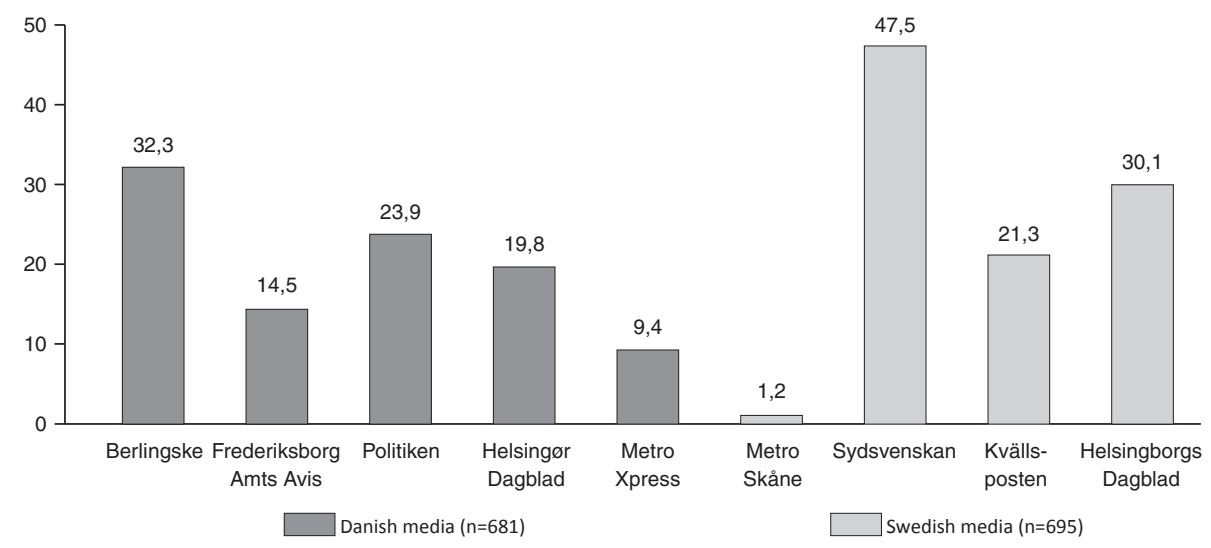

Figure 1. Swedish-Danish Öresund coverage 2002-2012 (per cent) 
The media coverage exhibits several differences. Metropolitan newspapers have the lowest coverage in both countries. This result is unexpected because these free newspapers are distributed to commuters, including travellers between Sweden and Denmark. In Sweden, Sydsvenskan has the most coverage by a large margin, while in Denmark, Berlingske and Politiken, the two national newspapers, rank first and second, respectively. Attention from local newspapers in both countries is quite sparse, with Helsingør Dagblad and Frederiksborg Amtsavis placing in the lower tier in Denmark. However, the Swedish Helsingborgs Dagblad ranks second. In the period analysed, there is a clear tendency towards writing fewer articles on Öresund-related subjects, as seen in Figure 2 , but at the same time, the length of articles has increased according to the analysis.

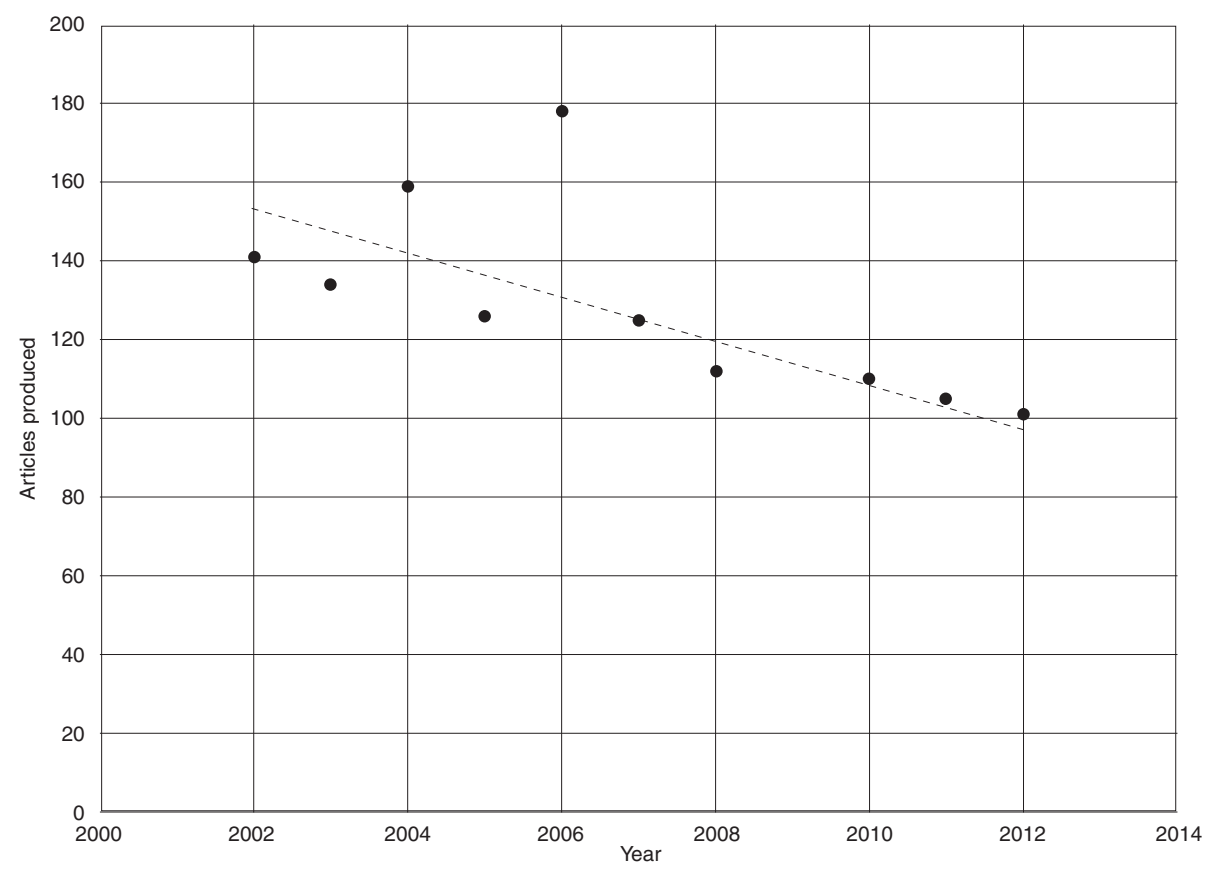

Figure 2. Coverage of Swedish-Danish news: Trends in articles 2002-2012

This decline in the production of articles with transborder themes could simply be due to budgetary constraints and a general decline in the media industry, but it could also result from the disappearance of financial support for this type of reporting, like support for the earlier EU project.

\section{Topics reported}

Overall, the analysed articles centre on crime and culture. As indicated in Figure 3, the reporting from both countries is rather similar, but there are small differences. Denmark reports more on consumption issues, as well as education, research, the environment, health, infrastructure, transport and labour market issues. Sweden reports more on classic hard news topics, such as the economy, elections and integration politics. There, unfortunately, are not sufficient data to elaborate on these differences. 


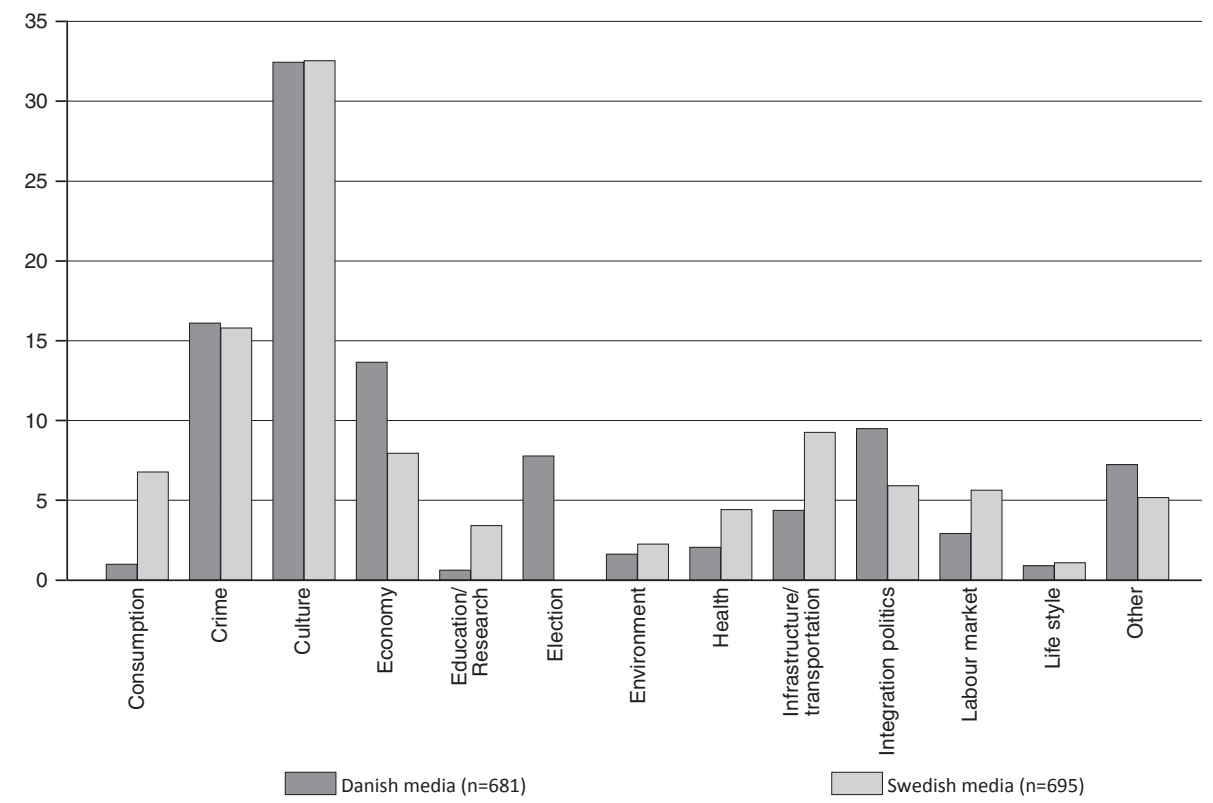

Figure 3. Topics in Öresund reporting (per cent)

When looking at the framing of the Öresund region in the newspapers, the differences become more pronounced. As seen in Figure 4, reporting on Öresund is very sparse in Denmark, whereas the Swedish media have a much higher tendency to report on Öresund as the main subject in articles.

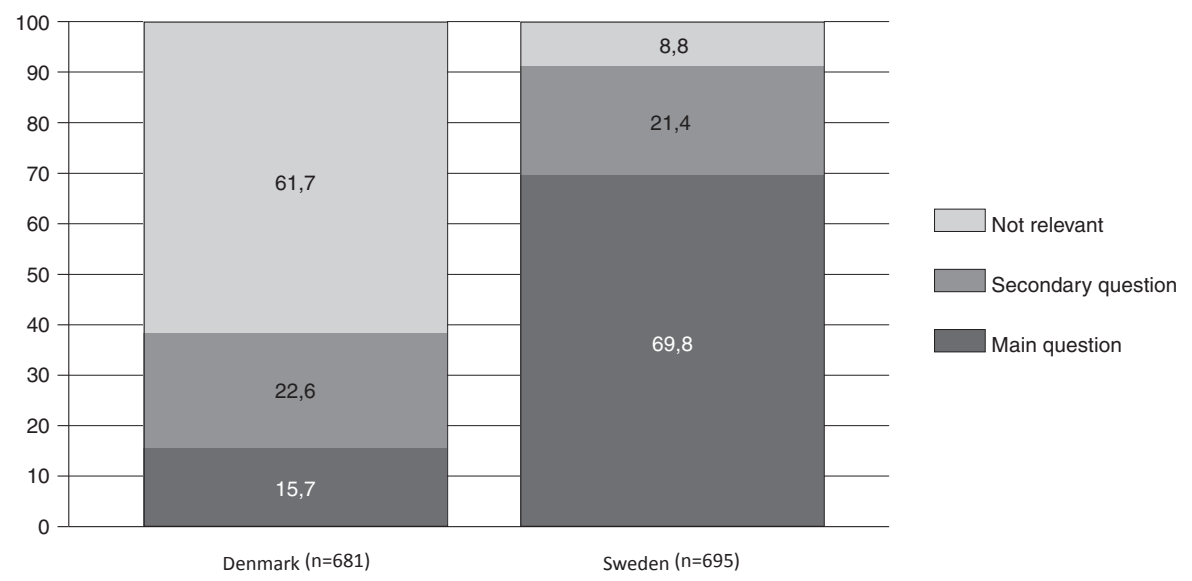

Figure 4. Articles with the Öresund region as the main subject 2002-2012 (per cent)

These differences are intensified when considering the type of journalism, as reported in Figure 5. Inspired by Lund (2001), Figure 5 presents the content ordered by type of journalism. Focus journalism stories are the kind every reporter wants to do, bringing attention to important subjects and doing original research and reporting. Routine journalism, in contrast, is reporting based on press releases and similar sources supplemented with original interviews or gathering of other materials to elaborate on the 
original material shared with the media by a third party. This kind of stories requires minimal journalistic effort. Service journalism is a type of fill-in-the-blanks reporting: re-writes of press releases, studies or other news material from professional sources without substantial editing.

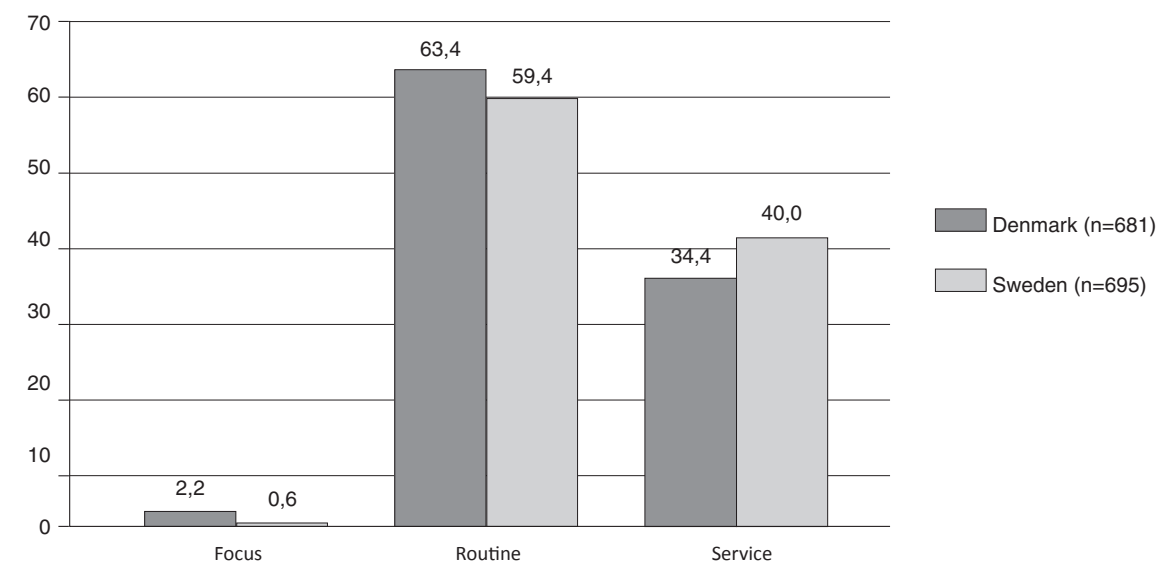

Figure 5. Type of journalism 2002-2012 (per cent)

Here, it becomes clear that, although the two countries have similar distributions of the three types of journalism, Swedish media display a slightly higher tendency towards performing routine journalism, whereas the tendency towards making service journalism is slightly higher in Denmark. Overall, the reporting in Swedish newspapers seems to be more thorough than in Danish.

In summary, the amount of coverage focusing on Danish-Swedish issues in the Öresund region has decreased every year since 2002. There is no significant difference in the amount of articles on Öresund in Danish and Swedish media, but the region is more frequently the main topic in Swedish than Danish newspapers. The media coverage in both countries consists mostly of routine and service journalism, not focus journalism. The dominant topics are crime and culture and, to a minor extent, the economy, politics, integration and other issues more directly related to Öresund as a region.

\section{Horizontal Europeanisation on the ground: the daily practice of transborder journalism}

This section picks up where most studies on Europeanisation exclusively using content analysis leave off. If we are to understand why the Europeanisation of news media coverage remains low, it is vital to take into account how journalists think and act, particularly in journalistic culture and newsroom practices. Newsroom practices involve journalists, editors and other individuals in the process of making news. On a daily basis, they negotiate making sense of the world and routinely organise and make the world comprehensible and meaningful for themselves and others. To the task of making sense of the world, they bring certain ideas and practices informed by the norms and rules by which day-to-day routines are organised (Allan 2004). The use of rules is not internalised mechanically but is a creative, interpretive activity. Nevertheless, journalists tend to conform to certain 
patterns when they operationalise the rules on a day-to-day basis. These patterns enable journalists to routinely process large amounts of information quickly (Tuchman 1978).

In this study, the Danish and Swedish journalists were asked about their routines when covering the region and what obstacles and challenges they face in doing so. Editors generally make decisions about the content and overall direction of news outlets and consequently have a crucial role in them. In line with Grieve's (2012) research, this study found that few organisational structures support transborder journalism production. In fact, such reporting depends mostly on the ambitions and interests of individual journalists. Swedish Sydsvenskan is the only newspaper with the explicit mission to produce transborder news. To fulfil this objective, Sydsvenskan based a reporter in Copenhagen until 2012. As a consequence of the economic downturn, the reporter instead commutes to Copenhagen two or three times a week. The reporter's duty is to provide a longer commentary on Copenhagen for the editorial section every week. Although none of the other interviewed journalists have not explicitly formulated editorial policies regarding coverage of the region or devoted additional resources to transborder activities, individual journalists ensure such coverage on a more or less regular basis.

Notwithstanding the ambitions of individual journalists, Swedish and Danish journalists have a similar way of selecting and evaluating which stories to include or exclude. First and foremost, the news must conform to existing media conventions. All the interviewed journalists stress that news about the Öresund region is selected not as it has a regional focus but as it fits conventional angles, whether local, national or foreign. The more nationally oriented the newspaper is, as are Berlingske and Politiken, the less important coverage of the region itself is. The Danish national newspapers do not differentiate between transborder and national Swedish news. Consequently, transborder news about southern Sweden (Skåne) is usually placed in the foreign section. Some exceptions occur when the national desk covers transborder news, such as events in transborder transportation and financial stories on some major companies.

The situation is similar among journalists working for local newspapers. Both Swedish and Danish local newspapers generally do not differentiate between transborder and local news. Although local Swedish newspapers have separate 'Copenhagen' and 'Helsingör' news sections which are filled on a regular basis, stories must have local value to gain journalists' attention. The interviewed journalists consequently remain focused on local and national news and angles.

\section{News values}

When selecting news, journalists follow more or less unspoken rules or codes of newsworthiness which help them justify certain events as newsworthy while excluding others (Gitlin 1980). The interviewed journalists follow conventional principles for selecting and valuing news. For example, the stories have to be interesting and relevant to their readers.

Both the Swedish and Danish journalists highly value experience-based journalism. The emphasis is on what the reader would experience as a cross-border tourist, particularly shopping, restaurants, museums and cultural events. Crime stories, infrastructure issues and cross-border transportation are deemed to be newsworthy. Crime issues can easily be formed into exciting stories through dramatization, while the latter topics might concern readers traveling across the borders. 
Stories are not selected explicitly as they are regional but as they are believed to be relevant and meaningful to readers. One Swedish reporter gave an example: If the hospital in Helsingör laid off many Danish nurses, then there would be no story to tell, but if the layoffs involved Swedish nurses, then it would become a newsworthy local story. A Danish local reporter expresses similar logic: 'If they are changing the harbour in Helsingborg, then the view from here will change when you are looking towards Sweden'.

Identification, cultural comparisons and local impact seem to be keywords in transborder reporting. Swedish journalists explain their reasoning. Issues concerning Danish daily life which are also relevant to Swedes, for instance, are considered newsworthy. Reports on how Danish day-cares function and how parental leave work provide examples against which Swedish readers can compare their own experiences. Less comparable issues, although hotly debated in Denmark, get less attention. For instance, the Danish pension system is perceived as too different to get the attention it deserves, according to a Swedish reporter. Stories about border barriers - in other words, bureaucratic problems - when living in one country and working in another are also considered to be of high value as they involve conflict between national institutions and affect citizens coping with daily life while caught between two systems.

If issues are not easily framed within identification, cultural comparison or local impact, then they have to be of significant magnitude to catch journalists' attention. A Danish local journalist sums up this reasoning: 'We draw a line with the border of the municipality, ... and if we write something about Helsingborg or Sweden, ... it will be comparisons and maybe some experience-based stories'.

When constructing the news, journalists negotiate between the rules and codes of newsworthiness, on one hand, and the imagined community of readers, on the other. News that conforms to journalistic principles of newsworthiness (i.e. relevance, personalisation, cultural specificity, conflict) and is relevant to the readers has greater chances of being selected. News based in the Öresund region is not selected and framed at the regional level but constructed and written to be experienced at either the local or the national level.

\section{Sources and co-operation}

In the newsgathering process, journalists rely on sources to have a steady stream of information from which to select stories. In interactions with different sources and each other, journalists develop ways of identifying newsworthy stories (Tuchman 1978). Even if Swedish and Danish journalists follow media across the border (e.g. newsletters, social media, newspapers), they both display a lack of good sources and networks on the other side of the border in their references to news sources. Reporters in both countries state that they sometimes find it difficult to understand how things work across the border, what sources to call or who to ask as the journalists do not know which authorities are in charge of specific areas. In these cases, they might ask their cross-border counterparts for help, either to understand complicated matters (to know what to ask) or to receive guidance on relevant sources (to know whom to ask). The Swedish journalists do not think that a better network would generate more stories as they 'get along' and are quite satisfied with their cross-border reporting.

Swedish and Danish media have engaged in some formal efforts to co-operate in regional news, use each other's knowledge and create synergy, but these efforts have not 
been successful. As mentioned, in 2000, Sydsvenskan and Berlingske Tidende launched a joint supplement, Öresundsnytt, which lasted only for a short time. According to a Sydsvenskan journalist, the initiative did not work as the newspapers could not agree upon anything: 'Two different countries, two different companies, two different cultures, ... so we could never really get along'. This end has been met by other formal, crossborder co-operation projects, such as an EU-supported public-service television project between Danish and Swedish television news outlets (Lorry and Sydnytt) and between the free newspapers MetroXpress and Metro.

Most recently, Helsingborgs Dagblad and Helsingör Dagblad started to co-operate and share resources in 2013 but halted this project stopped due to a lack of funds. The Helsingborgs Dagblad editor states that, if the co-operation had succeeded, the paper might not have had to assign its own reporter to cover Helsingör as it would receive news from its Danish counterpart, and vice versa. The editor continues: 'But then again, I think we would have it anyway [a reporter covering Helsingör]. What is in fact important to us... is our own eyes, our readers' eyes. 'Although both Swedish and Danish newspapers lack resources and might be able to save money through co-operation, cultural issues seem to be important obstacles to doing so.

\section{Region's resources and lack of political power}

News production is two sided: on one hand, journalists conform to certain preconceptions regarding what the implied reader wants to know, while on the other hand, these preconceptions are set against organisational and financial constraints. The Danish journalists state that a lack of resources is the main cause of the decreased cross-border reporting. The existing coverage is as to be expected with the limited resources available. A Danish reporter states that 'we can't take editorial resources and move to Öresund reporting. We have enough on our plate with covering our primary matters'. Other Danish journalists contend that, if Öresund coverage is to increase, then either the ' $C E O$ would have to prioritise it', or media outlets would need 'a dedicated employee for this'. In contrast to the Danish newspapers, the Swedish newspapers seem to have dedicated employees who make transborder news coverage happen, even though some outlets do not have organisational structures supporting transborder production. A Swedish editor states that he is pleased when journalists take the initiative to turn their ideas into crossborder reporting. Swedish opinion journalists sometimes write commentary to bring Danish and Swedish politicians' attention to border barriers and infrastructure issues and urge them to improve the infrastructure connections between the two countries. This approach does not seem to be present among Danish journalists, though.

Swedish journalists have difficulties estimating whether the amount of articles has decreased or increased over time but seem to agree that they have planned more crossborder reporting due to the economic situation. Most Swedish journalists do not think the economic situation has had any significant impact on the quality of transborder news - except for a senior journalist from Sydsvenskan once based in Copenhagen. This senior journalist states that Swedish media outlets not only miss breaking news but also cultural sensitivity by not having any journalists based in Denmark.

In addition to economic reasons, participants also mention lack of political power and awareness of the region. A Danish journalist states that: 'There would have to be 
political and cultural priorities in this, too. ... It would require that politicians start to take interest [in the region]'. The Swedish journalists are quite satisfied with their cross-border coverage and do not feel that they need to cover Denmark more than they already do. One Swedish editor states that, to increase cross-border coverage, better (political) integration must come first as it is not 'our mission to carry through regional integration - it's someone else's'.

\section{Conclusions}

In this section, we present the conclusions and discuss the results in relation to other studies on Europeanisation, regionalisation and the Öresund region. Based on the content analysis of Danish and Swedish media coverage from 2002 to 2012 and interviews conducted in 2013 and 2014 with journalists working in both Denmark and Sweden, we can draw three main conclusions. First, in the content analysis, we find what can best be described as Koopmans and Erbe's (2004) concept of weak horizontal Europeanisation. Second, the interviews show that reporters generally do not think about doing transborder reporting but, instead, follow the usual media logic of what is national, local and foreign. Third, when asked to evaluate the newsworthiness of the region, reporters argue that the integration of political issues is a prerequisite for increased reporting; in other words, as long as the national, regional and local politicians do not focus on the region, why should journalists?

Turning to the conclusion on weak horizontal Europeanisation first, we find that, in both Denmark and Sweden, there is generally little coverage of the other side and small focus on regional politics. That said, the weak horizontal Europeanisation found is stronger in Swedish media coverage. This difference might well result from the composition of the Swedish sample: regional newspapers, not the large national newspapers based in the Swedish capital of Stockholm. The result might also reflect, as other studies on the Öresund region have found, regional Swedish politicians' stronger focus on the region than both national and regional politicians in Denmark. That Copenhagen is the national capital and Malmö and Lund are not might create an imbalance in the relationship and make the Danish side stronger than the Swedish side. This situation could lead to a stronger focus on co-operation by Swedish media, whereas the Danish media might be more inclined to follow their own agenda than co-operate regionally. An OECD report (Nauwealers et al. 2013) points to this trend in an evaluation of the region's potential weaknesses. The report stresses that Denmark's stronger economic power and, in the same line of argument, the growing regional imbalances between the centre and periphery, is a growing concern. In short, Malmö and Lund might see immediate advantages from further regionalisation, while Danish politicians do not. The recent argument for re-branding the Öresund region as Greater Copenhagen ${ }^{4}$ can be seen as a result of this power imbalance, with the Danish capital clearly gaining the upper hand in the re-branding process.

Turning to the second conclusion, we find that the journalists interviewed do not think in terms of cross-border reporting but follow the usual media logic of what is national, local and foreign. The label 'Öresund region' is seldom used outside reporting on infrastructure and integration politics. As one reporter states, 'we draw a line with the border of the municipality'. As in other studies on regionalisation and transnationalisation (see, 
for instance, van Houtum and Naerssen 2001), we find that borders not only demarcate nations but also order and maintain individuals' identity and work routines, even if the work environment is increasingly borderless. Thus, reporters from both countries stress that reporting must be relevant to national audiences if they are to chase down a story. However, as found in the content analysis, the Swedes are more interested in the Danes than vice versa. Again, this difference might result from the power imbalance between the two nations.

Finally, we find that reporters from both countries stress that greater political interest in the region could increase reporting but insist that better integration of political issues must come before increased reporting. Again, this conclusion echoes those other studies on the Öresund region (e.g. Ek 2006, Hall 2008, Löfgren 2008) that both politicians and civil servants have attempted to create a vision of the Öresund region as a non-political project focused not on democratic or transparent regionalisation, but on the economy and mobility (Ek 2006). This vision has put the citizen as a commuter and a consumer at the centre of the debate and led to a focus on administrative and technical issues - topics not considered very newsworthy even in traditional national news coverage. In other words, turning the development of the Öresund region into a non-political, administrative project has led reporters to not feel obligated to the cover the region as a political project.

Comparing the present conclusions to those from other studies on the Öresund region, it seems clear that, in many ways, the weak horizontal Europeanisation found reflects the nature of Öresund as a transnational region - a non-political, largely administrative project that does not politically engage the citizens of the region and has an unequal power balance between the actors. The present study thus confirms van Houtom and van Naerssen's (2001) conceptual argumentation: 'It seems that the certainty, comfort, identity and security that a territorial order might render are given a higher value over a world of a non-territorial order' (134).

However, from an Europeanisation perspective, this research offers not bleak conclusions but several interesting ways for research to move forward. In 2012, the transnational News Öresund agency was launched. This independent news agency has a specific focus on the region and could help produce more news with a regional focus. Also, the recent refugee crisis in Europe has led to the reinstatement of border controls between Denmark and Sweden, which, in turn, has renewed public debate on the status of the region. Analysis of this debate might lead to new insights into the region's public and political status. Finally, the re-branding of the region as Greater Copenhagen should be the focus of future studies. Will the re-branding revitalise the region as both a political and a public project, or will the administrative focus that has so far dominated and contributed to making the region less newsworthy in the eyes of reporters and editors continue to dominate in the future?

\section{Notes}

1. http://www.oresundskomiteen.org/wp-content/uploads/2011/04/Infographic.png accessed 21/6 2016

2. http://www.oresundskomiteen.org/hem/publikationer/oresundsfakta/ accessed 21/6 2016

3. The compiled mean reliability rate was 80 per cent with differences in variables which required more interpretation by the coder. These differences, of course, are depicted in the analysis.

4. Among many possible references see: https://www.theguardian.com/world/2015/mar/05/denmark-wantsto-rebrand-part-of-sweden-as-greater-copenhagen accessed 21/6 2016 


\section{References}

Allan, Stuart (2004). News Culture. London: Open University Press.

Andersen, Benedict (1983). Imagined Communities: Reflections on the Origin and Spread of Nationalism. London: Verso.

Berg, Per-Olof, \& Löfgren, Orvar (2000). Studying the Birth of a Transnational Region, in Berg, Per-Olof; Linde-Laursen, Anders, \& Löfgren, Orvar (eds.) Invoking a Transnational Metropolis. The Making of the Öresund region. Lund: Studentlitteratur.

Brüggerman, Michael, \& Katharina Köningslöw (2009). "Let’s Talk about Europe": Why Europeanization Shows a Different face in Different Newspapers. European Journal of Communication 24(1): 27-48.

De Vreese, Claes H. (2003). Framing Europe - Television News and European Integration, Aksant Academic Publishers.

Edgren, Henrik (2014). Norden Hedder Vort Fosterland. Nordiskt och Skandinaviskt i Svensk Tidningsopinion Under Tidigt 1800-tal, pp. 15-46 in Hillström, Magdalena, \& Sanders, Hanne (eds.) Skandinavismen: En rörelse och en idé under 1800-talet. Stockholm: Makadam (Centrum för Öresundsstudier).

Ek, Richard (2006). The Ôresund Region - Six Years After the Bridge. Paper presented at the Nordic Network of the Regional Studies Association, Barlestrand.

Esmark, Anders, \& Ørsten, Mark (2008). Media and Politics in Denmark, pp. 25-44 in Aalberg, Toril, Strömbäck, Jesper, \& Ørsten, Mark (eds.) Communication Politics: Political Communication in the Nordic Countries. Gothenburg: Nordicom.

Falkheimer, Jesper (2004). Att Gestalta en Rregion: Källornas Strategier och Mediernas Föreställningar om Öresund. Stockholm: Makadam (Centrum för Danmarksstudier).

Falkheimer, Jesper (2016). Place Branding in the Öresund region: From a Transnational Region to a BiNational City Brand. Place Branding and Public Diplomacy, 12(2-3): 160-171.

Gitlin, Todd (1980). The Whole World Is Watching. London: University of California Press.

Grieves, Kevin (2012). Journalism Across Boundaries. New York: Palgrave Macmillan.

Hall, Patrik (2008). Opportunities for Democracy in Cross-border Regions? Lessons from the Øresund Region. Regional Studies, 42(3): 423-435.

Hallin, Daniel C., \& Mancini, Paolo (eds.) (2011). Comparing Media Systems Beyond the Western World. Cambridge: Cambridge University Press.

Hannerz, Ulf (1996). Transnational Connections: Culture, People, Places. London: Routledge.

Hospers, Gert-Jan (2006). Borders, Bridges and Branding: The Transformation of the Öresund region into an Imagined Space. European Planning Studies, 14(8):1015-1033.

Lamour, Christian, \& Nathalie Lorentz (2016). Regional News from New Regionalisation in Europe. A Look at Cross-Border Regionalisation from a Free Daily Reader's Perspective. Journal of European Integration, 1-14.

Lund, Anker Brink (2001). The Genealogy of News. Nordicom Review, 22: 37-43.

Lund, Anker Brink, Willig, Ida, \& Blach-Østen, Mark (eds.) (2009). Hvor Kommer Nyhederne Fra? Den Journalistiske Fødekcede i Danmark Før Og Nu. Århus: Ajour.

Löfgren, Orvar (2008). Regionauts: The Transformation of Cross-border Regions in Scandinavia. European Urban and Regional Studies, 15(3): 195-209.

Jansson, André, \& Falkheimer, Jesper (eds.) (2006). Geographies of Communication: The Spatial Turn in Media Studies. Gothenburg: Nordicom.

Kandyla, Anna-Angela, \& de Vreese, Claes (2011). News Media Representations of a Common EU Foreign and Security Policy. A Cross-national Content Analysis of CFSP Coverage in National Quality Newspapers. Comparative European Politics, 9(1): 52-75.

Koopmans, Ruud, \& Jessica Erbe (2004). Towards a European Public Sphere? Vertical and Horizontal Dimensions of Europeanized Political Communication. Innovation: The European Journal of Social Science Research, 17(2): 97-118.

Nauwelaers, Claire; Maguire, Karen, \& Ajmone Marsan, Giulia (2013). The Case of Öresund. Regions and Innovation: Collaborating Across Borders. OECD Regional Development Working Papers, no. 21.

Ørsten, Mark (2004). Transnational Politisk Journalistik. Roskilde Universitetscenter, Afdeling for Journalistik.

Palm, Göran (1996). Mellem Ideal och Verkelighed - Journalister om EU-journalistik. Rapport 169-3. Stockholm: Styrelsen för Psykologiskt Försvar

Stöber, Birgit Frauke (2004). Space, Mass Media and the Øresund Region - the Role of Mass Media in a Cross-border Region Building Project. København: Geografisk Institut.

Strömbäck, Jesper; Ørsten, Mark, \& Aalberg, Toril (2008). Communicating Politics: Political Communication in the Nordic Countries. Gothenburg: Nordicom. 
Tjernström, Vanni (2008). Nede i EU: En Nordisk Sammenligning, pp. 81-91 in Lund, Anker Brink; Willig, Ida, \& Blach-Ørsten, Mark (eds.) Hvor Kommer Nyhederne Fra. Aårhus: Ajour.

Tuchman, Gaye (1978). Making News. A Study in the Construction of Reality. New York: The Free Press.

Van Houtum, Henk, \& Van Naerssen, Ton (2002). Bordering, Ordering and Othering. Tijdschrift Voor Economische en Sociale Geografie, 93(2): 125-136.

Wieslander, Anna (1997). Att Bygga Öresundsregionen. Från 1960-talets Utvecklingsoptimism till 1990-talets Lapptäcksregionalism, in Tägil, Sven; Lindström, Fredrik, \& Ståhl, Solveig (eds.) Öresundsregionen Visioner och Verklighet. Meddelanden (7) från Erik Philip-Sörensens Stiftelse.

JESPER FALKHEIMER, Ph.D., Professor, Department of Strategic Communication, Lund University, jesper.falkheimer@isk.lu.se

MARK BLACH-ØRSTEN, Ph.D., Professor, Department of Communication and Arts, Roskilde University, oersten@ruc.dk

MADS KÆMSGAARD EBERHOLST, M.A., Journalist, Department of Communication and Arts, Roskilde University, makaeb@ruc.dk

VESELINKA MÖLLERSTRÖM, Ph.D., Senior Lecturer, Department of Strategic Communication, Lund University, veselinka.mollerstrom@isk.lu.se 